\title{
Discarding Reasonable EXPECTATIONS OF PRivacy: A CRITIQUE OF R. V. PATRICK
}

\author{
WILLIAM MACKINNON*
}

\section{INTRODUCTION}

Patrick, ${ }^{1}$ the Supreme Court of Canada's latest landmark privacy decision, will have a tremendous impact on policing in years to come. In Patrick, police officers sifted through the curbside garbage of Mr. Patrick, discovered compelling evidence of drug production in its contents, used the information to secure a warrant to enter his residence, and found an ecstasy lab once inside. ${ }^{2}$ The Supreme Court, in upholding the decision of the Alberta Court of Appeal, ${ }^{3}$ denied Patrick's claim to a reasonable expectation of privacy in his garbage. ${ }^{4}$

Patrick raises concerns that are significant and worth commenting on. The judgment correctly stipulates that curbside garbage is completely out of the control of those who place it there. This leaves lower court judges to undertake difficult grounds analyses before issuing warrants for searches of dwellings. ${ }^{5}$ Moreover, Binnie J., the majority judgment's author and a jurist who has historically taken a case by case approach to this area of the law, dubiously invoked a need for clarity in the jurisprudence as a reason to deny Patrick's claim. The chief consequence of this pursuit of clarity - that almost all claims to privacy in garbage are unprotected by Canadian Charter of Rights and Freedoms ${ }^{6}$ standards - is unfortunate. A police power to search garbage left at the back of a home is more open to abuse than one that permits anonymous searches at landfills, or the "gathering" of evidence at crime scenes and other places. ${ }^{7}$ Finally and most ominously, because the Court failed to recognize even the most limited privacy expectation in garbage, Patrick provides a clear and unfortunate licence: state actors, without legitimate reasons, may rummage through the garbage of politicians or judges they disapprove of, racial minority residents, disreputable members of society, and others who surface on their radar screen.

This comment is divided into three parts. The first portion outlines and explains the Patrick decision. The second part briefly canvasses a number of relevant authorities that predate Patrick. The third portion discusses Patrick in its jurisprudential context and argues

B.A., LL.B., LL.M. Many thanks to Don Stuart for helpful comments on an earlier draft of this piece. Thanks as well to the editors of the Alberta Law Review for their assistance in preparing this comment for publication. Errors are mine alone.

R. v. Patrick, 2009 SCC 17, [2009] 1 S.C.R. 579 [Patrick].

Ibid. at para. 1 .

The Alberta Court of Appeal's judgment formed the basis of my previous comment on this subject. Issues that were examined in that comment, such as the Court of Appeal's reliance on Fourth Amendment case law, are not re-examined here: see William MacKinnon, "Do We Throw Our Privacy Rights Out With the Trash? The Alberta Court of Appeal's Decision in R. v. Patrick,” Case Comment, (2008) 46 Alta. L. Rev. 225. For a meticulous analysis of these issues, see Richard Jochelson, "Trashcans and Constitutional Custodians: The Liminal Spaces of Privacy in the Wake of Patrick" (2009) 72 Sask. L. Rev. 199.

$4 \quad$ Patrick, supra note 1 at para. 73.

$5 \quad$ Indeed, in many cases the task of developing criteria that, in reasonable grounds analyses, can determine whether garbage that is out of the control of those who leave it there can actually be attributed to them, will be almost impossible. This problem will be discussed in greater detail later in this comment. Part I of the Constitution Act, 1982, being Schedule B to the Canada Act 1982 (U.K.), 1982, c. 11 [Charter].

For a discussion of gathering, see R. v. Leblanc (1981), 36 N.B.R. (2d) 675 (C.A.) [Leblanc]. 
that it represents a retrenchment from the purposive interpretation of the Charter envisioned by past jurists.

\section{THE PATRICK DECISION}

Mr. Patrick was convicted of trafficking in a controlled substance (ecstasy) after a trial at which evidence from his residence was introduced. Police officers, on several occasions, grabbed garbage bags from a receptacle at the back of Patrick's property. Inside these bags they found, among other things, torn up papers with chemical formulae written on them, gloves, used duct tape, items that were contaminated with ecstasy, and other things that were emitting a distinct odour of sassafras oil. ${ }^{8}$ This information "provided the primary basis" for the issuance of a search warrant for Patrick's home. ${ }^{9}$

Justice Binnie, who wrote for six of the seven judges who heard the appeal, identified two threshold issues: first, whether Patrick enjoyed a reasonable expectation of territorial privacy because the officers had to reach over his property line to secure the bags; and second, whether he had a reasonable expectation of informational privacy with respect to the contents of his garbage. These two categories — informational and territorial privacy — frequently overlap. Hence, there is a need for a contextual analysis with reference to the facts unique to each case. ${ }^{10}$

Justice Binnie began his analysis by drawing a distinction between a subjective expectation of privacy, where an individual determines his or her own definition of privacy, and an objective expectation of privacy, which "an independent and informed observer would reasonably expect." 11 Only claims that fall into the latter category by meeting the higher test of reasonableness will attract constitutional protection. Moreover, three issues were of concern to Justice Binnie: the balance between individual autonomy and effective law enforcement; the conduct of an accused and the impact this has on the reasonableness of his or her claim to privacy; and "the long-term consequences [of state action] for the due protection of privacy interests in our society." 12 These concerns are to be kept in mind while the following question is answered: has the claimant acted, with reference to the subject matter of his or her privacy claim, in such a manner as to lead a "reasonable and independent observer" to conclude that his or her assertion of privacy is reasonable in the "totality of the circumstances"? ${ }^{13}$

The "totality of the circumstances" test was canvassed in detail by Binnie J. in his judgment. Questions to be addressed included, among others:

What was the nature or subject matter of the evidence gathered by the police?

Did the appellant have a direct interest in the contents?

Patrick, supra note 1 at para. 3.

Ibid. at para. 1.

Ibid. at paras. 12, 26.

Ibid. at para. 16.

Ibid. at para. 20.

Ibid. at para. 25. 
Did the appellant have a subjective expectation of privacy in the informational content of the garbage?

If so, was the expectation objectively reasonable? ${ }^{14}$

Justice Binnie acknowledged that a great deal of information about the nature of a person's lifestyle choices and private habits can be gleaned from an examination of his or her garbage. The catalogue cited by the Court included: DNA, sexual paraphernalia, overdue bills, tax returns, and other personal items. ${ }^{15}$ From the Court's perspective, this was sufficient for Patrick to manifest a subjective expectation of privacy. ${ }^{16}$

Fatal to Patrick’s claim, wrote Binnie J., was its objective unreasonableness. First, with respect to territorial privacy, little significance was attributed to the "relatively peripheral" territorial intrusion that officers made when they reached over Patrick's property line to secure his garbage ${ }^{17}$ Furthermore, objectively speaking, Patrick abandoned his garbage along with any reasonable expectation of privacy in its contents when he placed it at the back of his property for municipal collection. After this, he risked that it would be disturbed by the public; as a result, the police could disturb it (seize it) as well. ${ }^{18}$

Moreover, Binnie J. placed almost all privacy claims to garbage in the same category: not protected by Charter standards. Garbage that is placed near the edge of a property can no longer be the subject of a successful privacy claim. One of the reasons for this is that it is difficult to determine at what point a homeowner's reasonable expectation of privacy in garbage is lost. ${ }^{19}$ Is it when it is placed on a curbside for municipal collection? Is it when it is picked up by municipal authorities? Is it when it arrives at the landfill? Is it when the decomposition process is complete? It would appear that the Court's unwillingness to answer these hard, hypothetical questions contributed to the undoing of Patrick's claim to privacy.

Justice Abella, in her own reasons, wrote that garbage, which necessarily reveals much about the individual who leaves it behind, should be protected from "indiscriminate state intrusion." ${ }^{20}$ Hence, a reasonable suspicion of wrongdoing should be a prerequisite to a constitutional search of a suspect's garbage. People who dispose of their belongings, wrote Abella J., are doing so without a choice in the matter; garbage, for reasons of hygiene, among others, must be alienated at some point. ${ }^{21}$ Moreover, in the totality of the circumstances, the fact that Patrick “technically 'abandoned'” his garbage was the only factor militating against his claim. ${ }^{22}$ Other important criteria, such as the intimacy of the information and the location of the search, supported his assertion of privacy. ${ }^{23}$ However, Abella J. added that discarded

Ibid. at para. 27 [emphasis in original].

Ibid. at para. 30 .

Ibid. at para. 37.

Ibid. at para. 45 .

Ibid. at para. 55.

Ibid. at para. 54 .

Ibid. at para. 77.

Ibid. at para. 88 .

Ibid. at para. 84 .

Ibid. at para. 85 . 
items can only have reduced reasonable privacy expectations ascribed to them. Thus, the lower standard of reasonable suspicion should govern. ${ }^{24}$

\section{THE JURISPRUDENTIAL FRAMEWORK: A BRIEF OVERVIEW}

Section 8 of the Charter protects the individual against unreasonable search or seizure. It reads: "Everyone has the right to be secure against unreasonable search or seizure." ${ }^{25} \mathrm{~A}$ discussion of judicial interpretations of this provision must begin with Hunter, ${ }^{26}$ the first authority to analyze it. In this famous case, the issue was whether provisions of the Combines Investigation $\mathrm{Act}^{27}$ were inconsistent with s. 8 of the Charter because they authorized unreasonable searches and seizures. Justice Dickson ruled that s. 8 and the constitutional apparatus to which it belongs are to be given "a broad, purposive" interpretation. ${ }^{28}$ Moreover, in Hunter, the Court introduced the reasonable expectation of privacy threshold to s. 8 jurisprudence; if constitutional protection is to be triggered, a claimant must establish a reasonable expectation of privacy in the item(s) or information seized. Finally, Dickson J. iterated that an "assessment of the constitutionality of a search and seizure, or of a statute authorizing a search or seizure, must focus on its 'reasonable' or 'unreasonable' impact." 29 Justice Dickson was clear that the focus will be the impact on the individual, not his or her property. ${ }^{30}$ In furtherance of this important distinction, he proclaimed that s. 8 "protects people, not places." 31

In Hunter, the Court made clear that a search carried out without a warrant is to be deemed presumptively unreasonable. Hence, before a search is undertaken, officers must establish reasonable and probable grounds to believe that evidence of unlawful behaviour will be discovered..$^{32}$ Reasonable and probable grounds are established (or not) with reference to the "totality of the circumstances." 33

Ibid. at para. 90. The "reasonable suspicion" threshold for garbage searches has been supported by authors in the United States: see e.g. Nancy Burke Rue, "Warrantless Search and Seizure of Curbside Garbage: California v. Greenwood, 108 S. Ct. 1625 (1988),” Case Comment, (1989) 58 U. Cin. L. Rev. 361.

Charter, supra note 6, s. 8.

Hunter v. Southam Inc., [1984] 2 S.C.R. 145 [Hunter].

R.S.C. 1970 , c. C-23.

Hunter, supra note 26 at 156.

Ibid. at 157.

The Supreme Court has been criticized for failing to hold true to this distinction and instead advancing a property-centric interpretation of s. 8: see Julia Lawn \& Andrew Bernstein, "Primacy to Privacy? The Supreme Court and the Privacy Threshold in Edwards" (1997) 55 U.T. Fac. L. Rev. 341.

31 Hunter, supra note 26 at 159, citing Stewart J. in Katz v. United States, 389 U.S. 347 at 351 (1967).

32 Hunter, ibid. at 160 . The Hunter requirement of reasonable and probable grounds has many exceptions to it. Border crossings and the regulatory context feature lower standards: see R. v. Simmons, [1988] 2 S.C.R. 495; R. v. Jacques, [1996] 3 S.C.R. 312; R. v. Monney, [1999] 1 S.C.R. 652; R. v. McKinlay Transport Ltd., [1990] 1 S.C.R. 627. For exceptions in the criminal context, see R. v. Caslake, [1998] 1 S.C.R. 51; R. v. Mann, 2004 SCC 52, [2004] 3 S.C.R. 59.

33 The most prominent authority on reasonable and probable grounds is probably still $R$. v. Debot, [1989] 2 S.C.R. 1140. The "totality of the circumstances test" articulated by Wilson J. canvassed a number of criteria, including: the reliability of the information predicting the commission of a criminal offence, the credibility of information received from an informant, and the extent of the police investigation undertaken prior to the search (at 1168). On occasion, because of the nature of a search, the Hunter standard of reasonable and probable grounds will be deemed too onerous and the lower standard of reasonable suspicion will govern. Reasonable suspicion was famously described by the U.S. Supreme Court in Alabama v. White, 496 U.S. 325 at 330 (1990):

Reasonable suspicion is a less demanding standard than probable cause [the American equivalent to reasonable and probable grounds] not only in the sense that reasonable suspicion can be established with information that is different in quantity or content than that required to establish probable cause, but also in the sense that reasonable suspicion can arise from information that is 
The nature of the information protected by the "reasonable expectation of privacy" threshold entrenched in Hunter has been the subject of a number of cases, the most prominent being Plant, ${ }^{34}$ which featured a police search of computer records. Justice Sopinka, the judgment's author, wrote:

In fostering the underlying values of dignity, integrity and autonomy, it is fitting that s. 8 of the Charter should seek to protect a biographical core of personal information which individuals in a free and democratic society would wish to maintain and control from dissemination to the state. This would include information which tends to reveal intimate details of the lifestyle and personal choices of the individual. ${ }^{35}$

Moreover, the Plant Court was sensibly disinclined to restrict successful privacy claims to items over which claimants have proprietary interests. ${ }^{36}$

Tessling, ${ }^{37}$ a case that has been criticized by many academics, ${ }^{38}$ addressed police use of a thermal imaging device used to take "heat" pictures of the respondent's home. The device, used in a flyover of Mr. Tessling's residence, was only capable of registering the distribution of heat as it left his home. Hence, the information acquired by authorities was sufficiently mundane that no reasonable expectation of privacy was infringed. ${ }^{39}$

Particularly interesting about Tessling is what the Court had to say about abandonment, the most fact sensitive aspect of a s. 8 analysis. Justice Binnie, the judgment's author, wrote: "[f]ew people think to conceal their home's heat loss profile, and would have difficulty doing so if they tried." 40 Thus, although Tessling was unable to establish a reasonable expectation of privacy because the scan revealed so little, he did not abandon the information; he had no choice but to relinquish control of it. ${ }^{41}$

In the Tessling judgment, Binnie J. alerted law enforcement, lower courts, and citizens to the complexity of the s. 8 analysis. The ceaseless evolution of technology, he reasoned, and the multiple ways in which technological developments can be used by police, means that hard and fast rules delineating the boundaries between privacy and law enforcement are not possible. ${ }^{42}$ Tomorrow's technology could be vastly different from today's, and it could be focused on citizens in a more efficient manner, gleaning more cogent information about them. Thus, the totality of the circumstances in each case must be examined such that

less reliable than that required to show probable cause.

R. v. Plant, [1993] 3 S.C.R. 281 [Plant].

Ibid. at 293 [emphasis added].

Ibid. at 291.

R. v. Tessling, 2004 SCC 67, [2004] 3 S.C.R. 432 [Tessling].

See Don Stuart, "Police Use of Sniffer Dogs Ought to be Subject to Charter Standards: Dangers of Tessling Come to Roost” (2005) 31 C.R. (6th) 255 at 256.

Tessling, supra note 37 at para. 55.

Ibid. at para. 41 .

According to the Supreme Court, dog sniffs are very much the same as FLIR scans. The only significant difference is that the emanations detected by drug dogs are capable of revealing the contents of a private area. Both heat and odour emissions are not abandoned; rather, there is no choice but to relinquish control of them. In its conception of abandonment, Patrick rests uneasily with Tessling and R. v. KangBrown, 2008 SCC 18, [2008] 1 S.C.R. 456.

$42 \quad$ Tessling, supra note 37 at para. 55. This case by case approach has been criticized because of the ambiguities it necessarily leaves in the jurisprudence. A good discussion can be found in Scott C. Hutchison, "Knowledge is Power: The Criminal Law, Openness and Privacy” (2005) 29 Sup. Ct. L. Rev. (2d) 419. This criticism was particularly intense in relation to the dog sniffing cases: see Sherri DavisBarron, “The Lawful Use of Drug Detector Dogs” (2007) 52 Crim. L.Q. 345. 
technological developments and novel search methods are addressed as they emerge. A case by case approach to $\mathrm{s} .8$ is consequently necessary. ${ }^{43}$

\title{
IV. ANAlysis: R. V. PATRICK \\ Within the ConteXt of Previous Authorities
}

\author{
In his disposition of Patrick, Binnie J. wrote:
}

The [garbage] bags were unprotected and within easy reach of anyone walking by in a public alleyway, including street people, bottle pickers, urban foragers, nosey neighbours and mischievous children, not to mention dogs and assorted wildlife, as well as the garbage collectors. ${ }^{44}$

If this statement is true such that garbage is, as Binnie J. describes it, "unprotected and within easy reach of anyone," it can be fairly asked, then, whether its presence at the curb of a home makes it attributable to the homeowner. The heat emissions in Tessling yielded limited information; yet, in important respects, these emissions were more significant than information secured from curbside garbage because they could be traced unmistakably to the home. ${ }^{45}$ In his disposition of Tessling, Binnie J., after ruling that the FLIR scan did not infringe on a reasonable expectation of privacy, made an important comment: "It is clear, to repeat, that at present no warrant could ever properly be granted solely on the basis of a FLIR image. ${ }^{\star 46}$ No such cautionary note about the significance of curbside garbage used to secure a warrant for the search of a dwelling is found in the Patrick judgment. ${ }^{47}$

In many cases, the significance of garbage is subject to misinterpretation. One imagines the spectre of a bank robber committing a robbery, leaving his targeted bank, and, after running a short distance, placing his weapon of choice in the "unprotected" garbage receptacle of a homeowner that is "within easy reach of anyone." Relying on the Patrick authority, officers carry out a search of all receptacles in the neighbourhood, discover the weapon, and use this as the primary basis to secure a warrant for a search of the home in front of which the receptacle sits. ${ }^{48}$ The result is an intrusive search of a private dwelling

$43 \quad$ Tessling, ibid.

$44 \quad$ Patrick, supra note 1 at para. 55 [emphasis added]. This will not always be the case; however, in most instances it will be.

45 Searches that take place at landfills or in the public domain are quite different. The evidence can still be recovered, but the risk that innocent people will have sinister discarded items attributed to them is diminished: see David W. Cunis, "California v. Greenwood: Discarding the Traditional Approach to the Search and Seizure of Garbage,” Note, (1989) 38 Cath. U. L. Rev. 543 at 558.

$46 \quad$ Tessling, supra note 37 at para. 55.

47 I do wish to stress that I am not saying that a grounds analysis was necessary here. Such a discussion would only take place if the Court had found a reasonable expectation of privacy. Moreover, there is always a risk that information will be wrongly attributed to a particular individual. For example, a drug peddler can put his drugs in the bag of another. But the risk is particularly acute when information secured from garbage forms the grounds used for an ensuing search. There will be instances when the analysis is easier (credit card records come to mind), but in many cases peoples' garbage can contain things that they did not put there. Some kind of indication, made in obiter, that great caution should be used in grounds analyses involving information secured from garbage was needed, and should have been included in the judgment.

48 The home, we must remember, is a deeply private setting. In R. v. Silveira, [1995] 2 S.C.R. 297 at para. 140, Cory J. wrote: "There is no place on earth where persons can have a greater expectation of privacy than within their 'dwelling-house."” 
whose occupant had nothing to do with the infraction. An American author has provided a particularly compelling example:

\begin{abstract}
Consider [the following] scenario: An old college friend is visiting you for a week at your new town house in an affluent suburb. His wife recently left him, and he was fired from his job. Most of his hardship is the result of a drug addiction he has battled for over a year. You confront him about this, you explain to him that it is finally time for serious changes in his life, and he eventually decides to get some help. As a first step, you convince him to get rid of any drugs he may have with him. He goes to the bedroom and returns within minutes with what looks to your untrained eye like cocaine. You are taken aback for a minute; but, determined to help your friend, you take the small plastic bags and throw them into the garbage can sitting in front of your garage door, knowing that the garbage will be picked up tomorrow. The evening ends on a hopeful note, and you are glad that you were able to help a close friend in a time of need. A week later, however, two police officers arrive at your door. They flash arrest and search warrants before your eyes, handcuff you, read the Miranda warnings, and begin turning your cozy town house inside out. The warrant explains that the vice squad found small quantities of cocaine in your garbage while conducting a random trash search in your town house complex. ${ }^{49}$
\end{abstract}

Now that Patrick has given state actors carte blanche to rummage through the garbage of the citizenry, it would be helpful for an appellate court to introduce an analytical framework unique to garbage such that, in the vast majority of cases, warrants are only issued when reasonable and probable grounds are established. One hopes that some criteria can be introduced and explained. ${ }^{50}$ Of course, because we do not know how acute this "false positives" risk is in relation to our trash, it made perfect sense for the Court to recognize a reduced privacy expectation in garbage receptacles at the back of homes, leaving it to Parliament to defend a legislative enactment permitting the police to snoop.

Moreover, as discussed, in his disposition of Tessling Binnie J. introduced the totality of the circumstances test for privacy claims. If the FLIR scan had yielded more significant information, the application of this circumstantial analysis may have led the Court to find an infringement of a reasonable expectation of privacy. But Binnie J. was careful to remind his readers of the facts before the Court: the FLIR scan revealed little about the home's occupants.

Mark C. Anderson, "United States v. Redmon: The Demise of Curtilage in Fourth Amendment Determinations? A Study of Garbage Searches on Common Property,” Note, (1999) 9 Widener J. Pub. L. 61 at 62 . A privacy expectation in garbage at the back of a property is supported not only by citizens' desire to keep their own information private, but also the legitimate apprehension that other things will be put into their receptacles by other people. Justice Binnie is correct in his analysis that garbage is out of the control of those who leave it there, but he fails to recognize the necessary corollary: reasonable people would not want to be held responsible for what finds its way into their garbage receptacles. Hence, there should be at least some reasonable suspicion of wrongdoing before a garbage search takes place at a dwelling.

50 Unfortunately, this is unlikely to happen because the threshold of reasonable and probable grounds, like proof beyond a reasonable doubt, is a fact sensitive common sense inference. What is needed is an understanding that items found in a garbage bin cannot always form the primary basis for a search of the dwelling in front of which they sit. Information found in a garbage bin, however incriminating, must be tied to the residence (and its occupants) in some way. This problem speaks to the reasonableness of the expectation that garbage remain unmolested unless there is a reason for it to be examined. When something incriminating is found in a garbage bin, it will be quite easy to patch together other reasons for searching a home. 
With the Tessling case by case backdrop in mind, it is strange to see Binnie J., in his disposition of Patrick, invoke a need for clarity as a reason to deny Patrick's claim to privacy:

The idea that s. 8 protects an individual's privacy in garbage until the last unpaid bill rots into dust, or the incriminating letters turn into muck and are no longer decipherable, is to my mind too extravagant to contemplate. It would require the entire municipal disposal system to be regarded as an extension, in terms of privacy, of the dwelling-house. Yet if there is to be a reasonable cut-off point, where is it to be located? The line must be easily intelligible to both police and homeowners. ${ }^{51}$

Justice Binnie's implicit point, that clarity in s. 8 case law is desirable, is helpful. However, in this paragraph he put his mind to hypothetical problems that were largely irrelevant to the case before the Court. Patrick was not asserting a privacy expectation over letters and bills rotting at a dump; rather, his claim extended only to a back alley search that targeted only him. If, for example, officers gathering evidence in a public park discovered Patrick's rotting, ecstasy contaminated garbage, this would have raised issues different from the ones before the Court. Such a search is clearly less intrusive and less perverse than indiscriminant examinations of the curbside garbage of people who are deemed by police, without any basis, to be the usual suspects in a neighbourhood. ${ }^{52}$

Moreover, a search that takes place at the landfill is less vulnerable to the hypothetical scenario of a weapon being left in somebody's garbage, only to be discovered by police and used as the primary basis for a search of his or her home. Landfill searches and the gathering of evidence could only contribute to grounds for the search of a home if information could be tied back to that particular residence. ${ }^{53}$ Furthermore, the other hypothetical problem discussed above - where the discovery of illicit drug traces in a garbage bin paved the way for an unfortunate misunderstanding — is both chilling and, for all we know, very real. Risk is a double-edged sword.

The point here is simple: the merits of privacy expectations in garbage vary considerably depending on the facts of each case. Some can be deemed reasonable; others clearly not. This article is not calling for a broad, judicially created rule stipulating that garbage cannot, under any circumstances, be examined by public authorities without prior authorization. But Binnie J.'s legitimate concern about clarity and the identification of the point at which garbage is no longer protected by Charter standards was no reason to deny any privacy expectation over any kind of discarded item left close to a property line, or anywhere else in the public domain. This, however, is precisely where Patrick leaves us.

$51 \quad$ Patrick, supra note 1 at para. 54 [emphasis added].

52 Anonymity lessens the intrusiveness of state action: see Steven Penney, "Conceptions of Privacy: A Comment on R. v. Kang-Brown and R. v. A.M.," Case Comment, (2008) 46 Alta. L. Rev. 203 at 217. A search that takes place at a dwelling is more intrusive and it allows state actors to indulge in "hit or miss" efforts that single out only the disreputable members of society: see Gary S. Levenson, "Constitutional Law - The Fourth Amendment Does Not Prohibit Warrantless Searches and Seizures of Garbage Containers Left at the Curb of a House - California v. Greenwood, 486 U.S. 35 (1988)," Case Comment, (1989-90) 39 Drake L. Rev. 775. Similar concerns have been raised in relation to data mining, a new search method that raises issues similar to garbage searches: see Ira S. Rubinstein, Ronald D. Lee \& Paul M. Schwartz, "Data Mining and Internet Profiling: Emerging Regulatory and Technological Approaches” (2008) 75 U. Chicago L. Rev. 261 at 263. 


\section{Conclusion}

Above all, privacy is an "evanescent" concept in the sense that it is difficult to arrive at a generally accepted definition of the idea. ${ }^{54}$ Thus, the appropriate balance between individual autonomy and law enforcement depends on which "independent and informed observer" 55 is consulted. In consequence, the relationship between subjective and objective conceptions of privacy requires greater analysis. An independent and informed observer with an income of, say, \$1 million would likely argue that Patrick ought to have purchased an incinerator to destroy his garbage. A homeless person, in contrast, would retort that it is impossible to destroy garbage without breaking the law. In the future, police, the citizenry, and judges will require a more developed idea of who this independent and informed observer really is, and what sociological realities shape his or her sense of privacy. ${ }^{56}$

Patrick's legacy is, of course, unwritten. For example, the impact the decision will have on bodily substances that we unavoidably excrete in public places is unknown. ${ }^{57}$ However, in this author's respectful opinion, one thing is clear: the Court, in its disposition of Patrick, did not give s. 8 the purposive interpretation envisioned by Dickson J. in Hunter. ${ }^{58}$

The differences between Binnie J.'s judgment and Abella J.'s reasons are clear, and revealing. Justice Binnie was focused on the risk that Patrick assumed that his privacy interests would be violated by other private citizens. This assumption of risk, quite surprisingly, did not merely reduce Patrick's reasonable privacy expectation, it took it away entirely. Moreover, the Court's understandable unwillingness to extend Charter scrutiny to garbage until its complete decomposition at the landfill served to distract it from the facts unique to Patrick's claim. In the final analysis, the Court missed the opportunity to prevent only the most perverse form of groundless garbage snooping: the kind that indiscriminately targets residents. ${ }^{59}$

$54 \quad$ Penney, supra note 52 at 203.

Charter, supra note 6, s. 8.

In my opinion, s. 9 of the Charter, which guarantees against arbitrary detention, requires a similar analysis.

Of course, it is likely that bodily substances will be deemed abandoned as well. It would appear that the Supreme Court would say that the many hairs, skin cells, and other DNA fragments we unavoidably leave in public places can be collected by police without constituting a seizure within the meaning of s. 8 of the Charter: see R. v. Dyment, [1988] 2 S.C.R. 417, contrasted with Leblanc, supra note 7. In any event, the battle over genetic privacy is surfacing on the U.S. radar screen in a particularly prominent way. The FBI's Combined DNA Index System, for example, links suspects to DNA fragments discovered at crime scenes. Of course, having to satisfy procedural hurdles such as probable cause (reasonable and probable grounds in the Canadian context) before a suspect's DNA can be analyzed makes the investigatory process more complicated. Extracting DNA from suspects without probable cause can be done, but it raises privacy issues: see Charles J. Nerko, "Assessing Fourth Amendment Challenges to DNA Extraction Statutes after Samson v. California” (2008) 77 Fordham L. Rev. 917 at 917-18. See also Elizabeth E. Joh, "Reclaiming 'Abandoned’ DNA: The Fourth Amendment and Genetic Privacy” (2006) 100 Nw. U.L. Rev. 857 at 882.

58 One of the major issues here is the ease with which perfectly innocent people can be singled out for intrusive state conduct: see David E. Steinberg, "Making Sense of Sense-Enhanced Searches” (1990) 74 Minn. L. Rev. 563 at 619; Steve Coughlan \& Marc S. Gorbet, "Nothing Plus Nothing Equals...Something? A Proposal for FLIR Warrants on Reasonable Suspicion” (2005) 23 C.R. (6th) 239 at 243.

$59 \quad$ In the case of California v. Greenwood, 486 U.S. 35 (1988), the most persuasive objections advanced by legal academics were to the effect that some procedural requirements should be satisfied before searches are carried out. It was the unwillingness on the part of the U.S. Supreme Court to attach even the most modest privacy expectation to garbage that spawned the fiercest criticism: see e.g. Madeline A. Herdrich, "California v. Greenwood: The Trashing of Privacy" (1989) 38 Am. U. L. Rev. 993 at 1015. Moreover, there are a couple of ways that the Court could have addressed the intrusiveness of 
The recent, relevant Supreme Court authorities were more favourable to Abella J.'s position. As discussed, in Tessling Binnie J. deemed it almost impossible for someone to prevent heat emissions from escaping a building. Justice Abella was correct to place garbage in the same category: information that must, at some point, be released into the public domain. ${ }^{60}$ Moreover, Abella J. astutely observed that because people have to relinquish control of their garbage, it would be more appropriate to distinguish between proprietary interests in it (no longer present) and claims to informational privacy in it (still valid under certain circumstances). And, with reference to the criteria enumerated in Plant, the information provided by garbage is more significant than what FLIR could deliver. ${ }^{61}$

But the most troubling aspect of Patrick is the extent to which it placed all privacy claims to garbage in the same category. Searches for discarded items that take place at landfills, on conveyor belts that usher garbage to landfills, or in public places are less perverse than the indiscriminant targeting of individual residents. In sum, proximity to the residence does (or at least should) matter in a reasonable expectation of privacy analysis. Moreover, Binnie J.'s attempt to inject clarity into the case law was unsuccessful; for the reasons identified by Abella J., Patrick and Tessling advance irreconcilable conceptions of abandonment. PostPatrick, abandonment remains an indefinable concept whose jurisprudential significance varies from case to case.

In the final analysis, a Court that has, historically, sensibly reconciled privacy and law enforcement has released one of its more questionable judgments.

garbage searches that take place at dwellings. First, the Court could have recognized a police power at common law to search when they have a reasonable suspicion to believe they can discover evidence of unlawful behaviour. This engages the so-called "ancillary powers" doctrine that traces its genesis to $R$. v. Waterfield (1963), [1964] 1 Q.B. 164 (C.A.). The Crown must demonstrate a lawful purpose and this lawful purpose must be deemed reasonable. In this author's opinion, it would have been vastly preferable for the Court to recognize a limited privacy expectation in garbage while leaving Parliament to introduce legislation giving police the power to conduct garbage searches. The legislative branch is usually, for a host of reasons, better equipped to make these decisions: see Tim Quigley, "Brief Investigatory Detentions: A Critique of R. v. Simpson,” Case Comment, (2004) 41 Alta. L. Rev. 935 at 950. garbage from working its way out of a home: see e.g. Hope Lynne Karp, “Trash: A Matter of Privacy?” (2000) 20 Pace L. Rev. 541 at 547-48. 